\title{
Guy Salmon
}

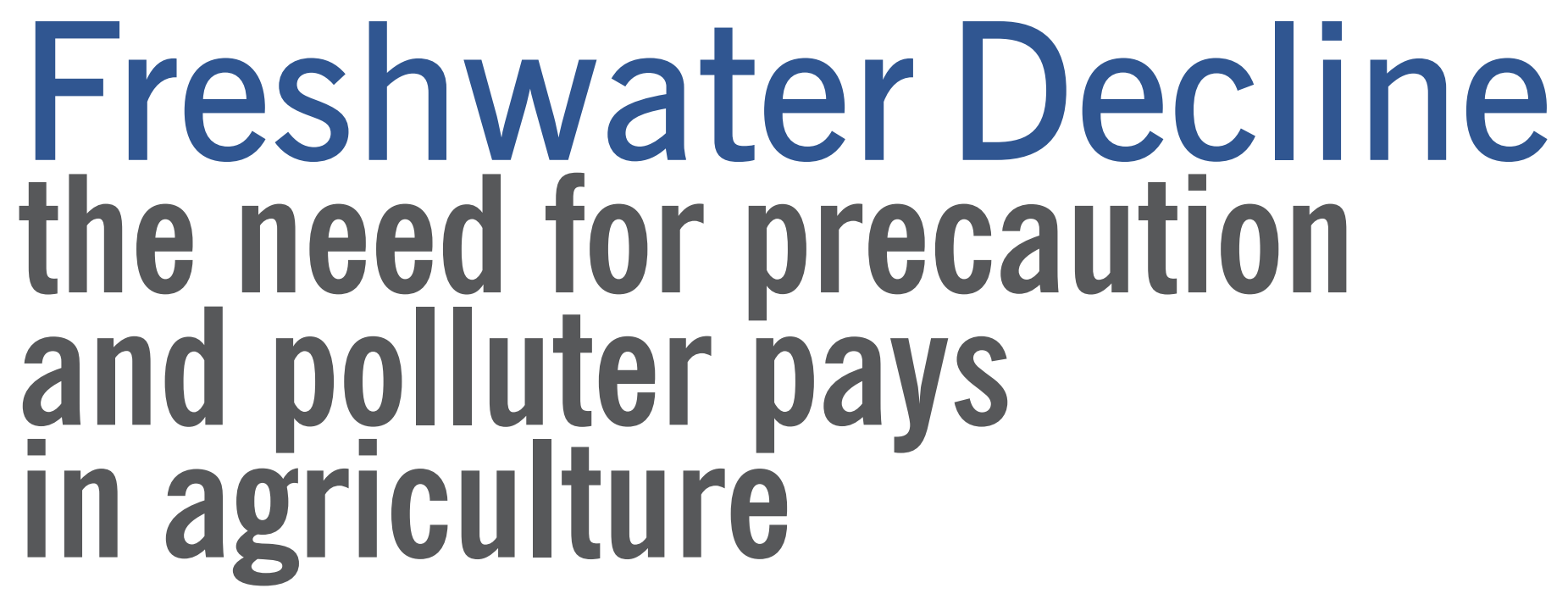

\section{Abstract}

Regional councils set objectives in 1992 to maintain and improve freshwater quality. Since then water quality in most agricultural areas has deteriorated. Proposals for freshwater reform need to understand the reasons for this long divergence between stated intentions and actual results.

A key driver has been the accretion over time of farmer entitlements to damage freshwater resources. This accretion has been overseen by regional councils, contrary to their own stated objectives. Councils' lack of precautionary action, and primary reliance on encouraging good management practices within existing livestockbased land uses, has allowed limits to be overshot. Livestock numbers will now have to reduce in many areas. Councils are unlikely to deliver such an outcome without major changes to the policy framework.

A government which has both economic and environmental goals needs policy instruments which can decouple agricultural value creation from environmental impacts. This requires an ability to apply the polluter pays principle, to drive eco-efficiency, innovation and land use change. Six major barriers exist to implementing polluter pays, which should be addressed if the pastoral export economy is to escape being hard-wired in pollution-intensive mode

Keywords good management practices in livestock production, farmer entitlements, multilevel governance, New Zealand regional councils, freshwater quality problems, polluter pays principle 
$\mathrm{O}$ ver the 30 years since regional councils were established, the desire and intention to maintain and improve freshwater quality has become increasingly salient. This is apparent in a series of reforms initiated by central government, and in the regional councils' own stated policy objectives. It is apparent also in the sentiments expressed by farming leaders, and in several published surveys of public opinion. Despite this, the measured states of ecological health and human health (for recreation and mahinga kai) have not generally improved. Instead, degraded freshwater quality is an issue in most of New Zealand's urban and rural areas, outside the conservation estate. While some of the most degraded water bodies are in urban areas, these make up only a small fraction of the total extent of degraded fresh waters.

Most waters in streams, rivers, lakes and estuaries are today dominated by agricultural run-off (Howard-Williams et al., 2011). Larned et al. conclude: 'Legacy effects, continued agricultural intensification and urban growth, and projections of future intensification ... all highlight the need for continual improvements in land use management, to limit future water-quality degradation' (Larned et al., 2016, p.25). It is noteworthy that the present government, through its reform programme Essential Freshwater, aims to do far more than just 'limit future degradation'. It boldly states: 'At the election the Government won a mandate, and we now carry a duty, to improve the quality of our rivers ... We're not going to keep kicking the can down the road and leave the hard issues for future generations' (Ministry for the Environment and Ministry for Primary Industries, 2018, p.4). This document further promises: 'In five years there will be a noticeable improvement in freshwater quality' (p.6). If the ministers' reform programme is to succeed, it is important to understand the reasons for the evident difficulty in limiting the adverse effects of agricultural land use intensification over the last 30 years. As a result, this article focuses on the dominant influence on rural freshwater quality, which today is agricultural land use.

\section{The accretion of farmer entitlements}

In New Zealand, legal property rights in land do not include rights to erode the soil, to drain wetlands, to take fresh water for irrigation, nor to pollute water bodies. The fact that these things are happening, often on a grand scale, is because they have been allowed to happen by the regional councils, to whom, under our freshwater management system, very extensive discretions and powers of control have been devolved.

Councils have functions, and must follow processes, prescribed under the Resource Management Act 1991 (RMA). In particular, they have responsibilities to set out their high-level strategic objectives and policies through regional policy nutrient discharge allocations for water bodies; and, arguably, non-complying practices that are informally allowed to continue for protracted periods as a result of council decisions, or through a lack of commitment to compliance enforcement.

The key point about how the system works in practice is that these two types of products are quite commonly not aligned with each other. Statements of good intentions are important for councillors' political purposes as they align with expressed wishes of the electorate and, in most regions, are necessary for councillors to win election. Entitlements, on the other hand, are of disproportionate importance for a small sub-section of the electorate comprising agricultural water users - those

\section{In New Zealand, legal property rights in land do not include rights to erode the soil, to drain wetlands, to take fresh water for irrigation, nor to pollute water bodies. The fact that these things are happening ... is because they have been allowed to happen by the regional councils ...}

statements, and their more detailed objectives, policies and rules in regional plans; in the case of certain activities allowed in the plans, they may issue consents, with specific conditions, to take, use or discharge into water. These consents confer legal rights in water for up to 35 years and may then be renewed.

Within this framework, regional councils may be viewed as producing two types of products. The first category may be described as statements of good intentions. This includes, notably, policy objectives; limits on the taking of water, and on discharges into water; and targets (limits which are to be met at a date in the future). The second category of council product may be described as entitlements. This includes: consents; rules which establish permitted activities; certificates of compliance; grandparented (see below) engaged in the taking of water or discharging contaminants into water. Water users seek certainty of entitlements as a basis for their borrowings and ongoing investments in their businesses. They oppose any reduction in entitlements which may affect the value of their land. These motivations are perhaps inevitable; but the regulatory system is clearly failing when councils take decisions to create entitlements which are not in alignment with their own policies, limits and targets.

In 1992, as required by the Resource Management Act, every regional council consulted the public in its region and published a regional policy statement. Every regional policy statement contained strategic objectives to maintain or improve freshwater quality. Since 1992, longestablished and conspicuous adverse trends in water quality have made it clear that 
these objectives have not been delivered on in agricultural areas in most regions. This is partly because regional plans, developed to implement the councils' stated objectives, generally placed the main emphasis on 'education', that is, encouraging voluntary uptake of good management practice by farmers. This is a doctrine which, in intensively farmed areas, has not proved to be consistent with the objective of improving water quality (see next section). But of particular significance is the fact that many councils went further, to allow activities and practices to become established and to persist which they must
New Zealand outside Canterbury. The role of certificates of compliance is to convert permitted activities into a legal entitlement attached to an individual property, essentially equivalent to a consent. The certificates have been in high demand in many regions because they protect property owners against any new rules which may be introduced by way of a proposed plan.

(2) By delaying the establishment of any form of limits, and in the meantime issuing consents which cumulatively overshoot the needed limits. Most councils established no meaningful

\section{Since 1992, long-established and conspicuous adverse trends in water quality have made it clear that these objectives have not been delivered on in agricultural areas in most regions.}

have known were inconsistent with achieving their stated objectives. In doing so, they established accretions to the bundle of rights and entitlements which are assumed and relied upon by farmers. Five main routes to council-established accretions of farmer entitlements may be identified:

(1) By introducing rules which create certain permitted activities, and by issuing certificates of compliance which then protect those activities against future rule changes. In many regions experiencing dairy industry growth, permitted activity status was extended to allowing stock access to waterways and unlimited fertiliser application. Fortunately, Fonterra took an initiative to secure fencing of larger dairying streams in 2001 and some councils followed suit in their plans, but intensive sheep and beef farming still does not require fencing in a number of council plans, and national stream fencing regulations announced in 2017 have never been gazetted. Unlimited fertiliser application continues to be an accreted farmer entitlement in most parts of limits on issuing water consents during the first 20 years of the RMA, although, according to a 2008 study by the New Zealand Business Council for Sustainable Development based on council staff appraisals, most catchments were close to fully allocated, or over-allocated, by that date. Canterbury was the most conspicuous example of consents overshooting needed limits. A 'gold rush' for water for irrigated dairying starting from the early 1990s had led to unrestrained consent issuance for water takes; the council subsequently refused to agree to environmentalists' requests to seek powers for a moratorium on further consenting; and dramatic drops in groundwater levels occurred during the irrigation season, with parallel effects on lowland stream flows. In 2006 came the announcement of the Programme for the Restoration of Lowland Streams, which failed, and a strategy was advanced for building water storages which could take pressure off the aquifers without curbing farming activity. However, the combination of these policies with unlimited fertiliser application as a permitted use led to a widespread and rapid build-up of groundwater nitrates in irrigated farming areas. This rise is ongoing despite the recent introduction of limits and targets. (Parliament dismissed the council in 2010 and commissioners were appointed, in what has been so far an only partially successful effort to bring water management under control.)

(3) By protecting some or all existing land and water users once recognised limits have been overshot by the proposing of rules creating grandparenting arrangements. Grandparenting involves the conferring of an exclusive privilege to pollute water (or emit greenhouse gases) at or near existing levels on a politically powerful group. It thereby defers - for a decade or more, with likelihood of renewal - any need to take responsibility for the resulting environmental impacts. In the absence of statutory authority to auction, or progressively charge for, rights to use or take water, grandparenting by regulatory fiat has become the default allocation strategy adopted by regional councils. To provide a genuine, secondbest solution to the need to allocate responsibilities for meeting limits while providing for a transition, any grandparenting should include a binding exit strategy which clearly signals to land users the imperatives of early change, including, for many, the need for a change of land use. This, however, is far from the minds of most regional councils which propose grandparenting arrangements. For example, an 80 -year period to achieve water quality targets is embodied in Waikato's PC 1 proposal, which is accordingly very modest in the demands it makes of its major source of nutrient contamination, the dairy industry, targeting only the most egregious $25 \%$ of polluters for reductions in the coming decade, while locking in entitlements for the other $75 \%$ to continue their present levels of pollution.

(4) By excessively protracted delays in taking compliance enforcement action against 
non-complying practices. While not strictly speaking an entitlement, an ability to rely on non-enforcement of consent conditions created something akin to it for dairy farmers in some regions for many years. Most councils have significantly improved their compliance monitoring and enforcement activity in recent years, but some disturbing reports still come to light. For example, in Waikato in October 2018, 20 years after dairy shed effluent management rules were first introduced and 11 years after the current plan provisions came into force, it was reported that grossly undersized effluent storage, likely to lead to pollution incidents, still existed on 19\% of the region's 4,500 dairy farms, that only 76 of 432 high-risk farms asked to upgrade had complied, and that at the current rate of progress it would take 27 years for them to comply (Farmers Weekly, 2018).

(5) By introducing payments for good environmental practice (which effectively confer a right to bad practice on those farmers not being paid to desist). There is a long-established practice, predating the establishment of regional councils, of entitling the farming of highly erodible land while encouraging soil erosion plantings with grants. This combination has the unwanted effects of displacing private forestry investment and slowing down the rate of land protection to the rate at which public funds are made available. Under this policy, retirement of highly erodible land from pastoral use will take many decades.

Attempted restraint of the accretions process In 2014 the regional plan ('One Plan') of the Horizons Regional Council (ManawatūWhanganui) entered into force after years of debate and litigation. For the first time, some farmers were required to obtain intensive land use consents, to ensure that the plan's freshwater limits were met. It soon became apparent that the council's primary concern was to ensure that existing intensive farming businesses were not forced by these limits into de-intensifying or changing land use. Environmentalists contended that many consents were being issued illegally, and that a council resolution which appeared to direct officers to do this was also illegal. In 2017 the Environment Court upheld these claims, saying:

Economic consequences for private individuals are an inevitable corollary of regulation in the public interest. That is not a reason to manipulate or pervert plan implementation ... The potential environmental impact of the activities in question is very significant ... The declarations are required to protect the integrity of the One Plan and the community's confidence in Council decision-making. ([2017] NZEnvC37, para 182)
It appeared that such a combination of outcomes would be politically unacceptable to the council, which in April 2019 announced that it would simply change the plan to achieve its original intention, 'water quality improvement within the means of most farmers.' ${ }^{1}$ Litigation over this could well take years to resolve. The experience suggests that, notwithstanding the views of the Environment Court, the real power lies with the regional council, even if it is only a power to delay.

Many councils have shown that politically driven delays in introducing or enforcing limits are a key to the accretion process, since, once land use intensification has been allowed to occur, even if it damages freshwater resources it becomes

\section{... once land use intensification has been allowed to occur, even if it damages freshwater resources it becomes extremely difficult to reverse.}

The council revoked its resolution and stopped illegally issuing consents. But having already apparently committed, in its earlier consents, too much of the known, total allowable envelope of nitrogen discharges, the council was unable to consent a further 118 operating dairy farms and 60 commercial vegetable growers, who have simply continued to operate without consents. An independent report commissioned by the council estimated the impact on farms of the One Plan continuing in force, assuming an uncontroversial updating of a technical table in the plan. The report said:

nitrogen losses would drop by over 200 tonnes[/yr] (40\%) and milk production by over 700 tonnes over 20 years (5\%). However, some farms would still struggle to remain financially viable ... It is possible that some of the affected farmers would consider amalgamating and others to change their existing landuse away from dairying. (Parminter, Ridsdale and Bryant, 2018, p.7) extremely difficult to reverse. Indeed, the significance of allowing accretions to become established becomes clearer when the psychology and politics of trying to reverse them later are brought into focus. Kahnemann (2011) has shown that risk aversion is asymmetrical: people are more willing to act to avert a loss than to achieve again. Olson (1971) has shown that in the pursuit of public goods, power is also asymmetrical: the common good of large latent groups is poorly incentivised compared to the strong incentives which can operate in small groups, such as those with vested interests at stake. It is the combined force of these two well-known tendencies of human behaviour that makes the ongoing accretions issue so critical in the operation of limits-based governance.

Various technical devices may then be used which purport to create win-wins for both freshwater limits and farm profitability, and it is the promise of these devices that is commonly relied upon to justify nonregulatory approaches by councils. Some devices are collective good projects involving community water storage, 
managed aquifer recharge or the management of groundwater nitrate attenuation, but for the most part they comprise good management practices (GMPs) which are dependent on individual landowner actions. The alleged promise of GMPs for solving freshwater problems has strongly underpinned councils' characteristic delays in introducing and implementing freshwater limits. The problematic nature of reliance on GMPs for delivering results in a limits-based system is explored next. rather than curbing, the innovation and land use changes that New Zealand needs.

Both assumptions need to be carefully examined in a country like New Zealand, whose main environmental problems originate in large measure from intensive, grass-fed livestock farming, and whose soils and climate offer us many other land use options. In 2001 the dairy industry began an experiment which tested the first assumption. The industry established five experimental stream catchments,

\section{The environmental results achieved in the [Bog Burn in Southland, Waikakahi in Canterbury, Waiokura in Taranaki and Toenepi in Waikato] catchments are, from the perspective of a government wanting timely improvements in water quality, mostly not encouraging.}

\section{The doctrine of encouraging good management practice}

Good management practices, and supporting measures for their dissemination such as catchment management groups and farm environmental plans, are clearly good things in themselves. The issues for debate are whether relying on them is really an adequate response by itself; and, where it is not, what kind of relationship should exist between them and the regulatory framework. There is optimism in some quarters that simply adding a regulatory 'nudge' to farmer uptake of GMPs, without creating impetus for reducing livestock numbers, would meet the government's objectives. This view embodies two assumptions, each of which is challenged in this section. The assumptions are:

- that if existing farmers were all to apply GMPs, environmental outcomes would then be satisfactory; and

- that a regulatory system based around GMPs, and therefore controlling how farming was done, could be designed and operated in a way that stimulated, representative of intensive dairy farming across New Zealand, introduced a range of GMPs, and measured the overall effects on stream water quality.

One of these catchments, Inchbonnie, is really only representative of the West Coast, where very high rainfall, very high flood frequency and proximity of indigenous forest appears to provide a relatively resilient environment for intensive dairying, although nitrogen flows from dairying to Lake Brunner may have to be managed in future (Wilcock et al. 2013a). Water quality in the Inchbonnie catchment is no longer being monitored. The other four GMP monitoring catchments, which are further examined here, are Bog Burn in Southland, Waikakahi in Canterbury, Waiokura in Taranaki and Toenepi in Waikato. The industry developed a series of GMPs and obtained good uptake of them among farmers in these four catchments. The main GMPs involved streamside fencing and planting, and improved management of dairy shed effluent, plus upgrading of irrigation technology (in Waikakahi) and of winter feed management (Bog Burn).

The environmental results achieved in these four catchments are, from the perspective of a government wanting timely improvements in water quality, mostly not encouraging. After 18 years of monitoring (including recent regional council results where available), the level of faecal contamination in the four catchments remains in the worst $25 \%$ of sites monitored in New Zealand commonly unsuitable for swimming or gathering mahinga kai. ${ }^{2}$ While concentrations of total suspended solids, and water clarity, have improved in all four streams, indicators of poor ecological health which were measured at the outset of the experiment remained largely unchanged when trend analyses were performed with data up to 2013 (WrightStow and Wilcock, 2017). These results probably reflect the influence of multiple stressors, including total nitrogen, the latter perhaps acting indirectly. Marginal improvements were reported on some measures at Toenepi, but the Land Air Water Aotearoa (LAWA) website records that in this stream, MCI (macroinvertebrate index, the preferred measure of ecosystem health) remains 'poor' at 68. Only at Waiokura is there an encouraging picture, mainly apparent since 2013, with MCI near Manaia now rated 'good' at 103.5. None of the catchments exhibit overall the compulsory national values of ecosystem and human health defined in the existing National Policy Statement for Freshwater Management, a document which is itself regarded as inadequate by the present government.

One response to this situation would simply be to introduce some regulatory compulsion on laggards to adopt GMPs, perhaps by requiring farms to have certified farm environmental plans, of the sort already used and promoted by industry groups. Wilcock et al. (2013b) say that for various reasons, including market forces influencing farm incomes and costs, and a slow rate of farmer adoption of some GMPs, monitoring programmes 'need to be much longer than ten years if they are to detect changes in water quality caused by farmer actions' (p.410). Wright-Stow and Wilcock (2017) offer some optimism 
that the ecological health of the GMP catchments might gradually improve over several decades. But neither paper offers evidence that GMPs alone, even with regulatory compulsion driving their uptake, would enable New Zealand's more intensively farmed and/or fragile areas to meet catchment limits for ecosystem and human health based on the national policy statement. If we are serious about meeting limits for these values, and especially if, like the government, we are wanting timely delivery, a more precautionary approach seems to be called for.

This raises the question of whether livestock intensity in some areas, and livestock numbers overall, might need to be reduced, through policies favouring deintensification and diversification of land use. The case for such policies is strongly reinforced if climate policy is integrated into the policy frame, although freshwater policymakers probably cannot rely on livestock farmers being required to pay the full social cost of their climate emissions for a very long time. So what happens now in freshwater regulation, and the form it takes, still matters. Arguably, we need a system capable of stimulating reduced livestock intensity and changes of land use in those catchments - probably many where simply implementing GMPs for existing livestock farming systems will not be sufficient. A system of farm environmental plans focused on GMPs and using certifying consultants accountable to regional councils may be under consideration, but this is an unlikely vehicle for ensuring that intensive land users change or exit. Such a system amounts to input regulation tailored to incumbent land use systems (intensive sheep and beef, dairy or deer farming) and based on 'best practicable means', a commonly used strategy in resource management which implies that while better emission standards may be achievable, industry should not necessarily be required to implement them if this would not be practicable especially with respect to costs' (Calow, 2009, p.11). Such a system is attractive to sectoral interests because its effect is to protect incumbents against competing land uses which could perform better. Although widely used overseas, such an approach seems ultimately at odds with the system of 'environmental bottom lines' based on 'hard limits' that New Zealand has adopted, following the consensus of the Land and Water Forum.

\section{Explanations for regional council behaviour}

It is argued above that regional councils' responses to freshwater decline have long emphasised encouraging good management practice by voluntary means while enabling farmers to accrete entitlements to degrade fresh water, accretions that are contrary to the councils' own stated objectives; and that some councils are reluctant to countenance any either central government or the courts to require councils to comply with their own plans. The evident unpopularity of the 'removal of democracy' at Environment Canterbury, and of legislative proposals to empower ministers to write text into regional plans, appears to date to have inhibited ministers from exercising powers which could be perceived as 'overriding local democracy' for the sake of meeting national objectives for water quality. Finally, the cumbersome nature of the plan change process, commonly requiring two rounds of hearings, drives delay and makes it difficult to curb the creeping process of accretions.

\section{... some councils are reluctant to countenance any significant reductions in existing livestock farms to achieve water quality objectives.}

significant reductions in existing livestock farms to achieve water quality objectives. What explanations can be inferred for this pattern of behaviour? Possible explanations may be examined under four headings: enablers; drivers; contextual factors; and challenges attributable to the logic of collective action. The enablers are susceptible to early central government action, while the other factors, although important, will take longer to change; they are addressed here only briefly.

First, the enablers notably include the fact that the highly discretionary section 104 of the Resource Management Act does not require council-issued consents to comply with, or even be consistent with, the objectives, policies and rules set out in plans. Rather, the requirement is merely to 'have regard to' these. Also, while since 2011 there has been the National Policy Statement for Freshwater Management, which has legal force under the RMA, it currently still allows councils until 2030 to produce their freshwater plans. Farms using certificates of compliance issued under pre-existing rules may not be affected by the 2011 policy until the 2040s. Furthermore, it has not proved easy for
Second, the drivers of regional council behaviour include, notably, the farming and rural industry lobby groups, which are well-organised and resourced, and whose pressure on councils has been especially influential in regions where anxiety exists about perceived risks of socio-economic decline.

Third, there are contextual factors which may affect regional council behaviour, including rural-urban differences and tensions between regional and district councils which leave little room for middle ground. New Zealand's prevailing political culture has arguably become more fragmented and polarised, albeit not to the extent seen in some countries. Polarisation has sometimes been mellowed by collaborative efforts, such as the Manawatū River Leaders' Accord. ${ }^{3}$

Fourth, there are challenges associated with the logic of collective action (Olson, 1971; Lubell et al., 2006), which lead to power asymmetries manifested in electorate awareness of issues, in council elections and in regional decision-making. While public participation opportunities are provided for by law, including for submissions, hearings and court appeals, 
individuals or small groups who engage in these activities face significant personal costs. When compared to the corresponding individual benefits of their actions, which are spread thinly and widely, the imbalance incentivises most individuals to become inactive free-riders. The minister for the environment's technical advisory group wrote in 2009:

A series of public awareness surveys conducted by Environment Canterbury (ECan) every two years since its formation shows a fairly consistent pattern: only about two percent of well placed themselves to reverse this situation in a timely manner. Of course, councils do not operate in isolation, but form part of a multi-level governance structure which includes important roles for the Environment Court and (at least since 2010-11) for central government, which we consider next.

\section{Issues with the multi-level governance} structure

Central government has long struggled to fulfil its intended statutory roles of providing a framework of national policy and standards, and of presenting its views

\section{The Labour Party's 2017 election policy of bringing fresh water into public ownership did not survive coalition negotiations, and the Ardern government's policy now echoes that of the Key government in insisting that no one owns water.}

Canterbury residents can name their local, elected ECan councillor, and only about ten percent can name the chairman of the council. It is likely that a similar pattern holds for other regional councils. The lack of a strong political mandate appears to hamper many regional councils in their dealings with other councils and with sector groups. This creates a risk of sector capture, and contributes to an evident difficulty in resolving contentious issues. (Minister for the Environment's Technical Advisory Group, 2009, p.54)

The situation described has been helpful for well-organised vested interests. According to McNeill (2008), farmers, despite being less than $1 \%$ of the total population, comprised $38 \%$ of regional councillors and formed a majority in five of the 12 regional councils.

In conclusion, regional councils have enabled widespread overshooting of freshwater limits to occur, and they are not in RMA planning processes. Numerous national policy initiatives came to nothing during the first 20 years of the RMA. Only following the 2009 formation of the Land and Water Forum, a consensus-building body bringing together environmentalists, iwi, the primary sector and energy companies, did progress get under way, leading notably to the National Policy Statement for Freshwater Management in 2011, which was added to in 2014 and 2017. Even so, a significant proportion of the forum's recommendations had not been implemented during its nine-year lifetime. The weak leadership of successive central governments on freshwater policy reflects that they have long seen their first priority as promoting economic growth, mainly through primary sector exporting. This has also, arguably, given primary sector interests a longstanding dominant influence over environmental policies. This continues to make it difficult to apply the polluter pays principle in agriculture, despite support for developing economic instruments based on this approach from the Tax Working Group (2019), the Interim Climate Change Committee (2018) and the Waikato Regional Council (2017).

The prevailing political context has also discouraged government control of mechanisms for holding farmers accountable for their environmental practices, mechanisms which are effectively privatised. Overseer, the computer model developed by fertiliser interests (with a minor public shareholding) to enable farmers to better manage their nutrient leakage, has been adopted by many regional councils to hold farmers accountable for discharges into water bodies which have nitrogen limits. The model is useful for councils devising grandparenting schemes. But the way in which it has been developed, the inadequate scope of its calibration, and its lack of transparency appear to make it unfit for the purpose of holding farmers accountable at the property level; consideration should be given to bringing Overseer into public ownership (Parliamentary Commissioner for the Environment, 2018). Similarly, New Zealand's systems for writing and certifying farm environmental plans, which have largely been privately developed by primary sector industry groups, are now being considered for adaptation to a public regulatory purpose. This arguably needs very careful scrutiny also, if the system is to avoid industry capture and the disincentives to innovation and land use change that are associated with input regulation and 'best practicable means' policy approaches in Europe and North America.

While central government has been proactive in recent decades in addressing issues around the Treaty of Waitangi and has formally acknowledged iwi rights and interests in fresh water, this has generally not extended to negotiating settlements. The Labour Party's 2017 election policy of bringing fresh water into public ownership did not survive coalition negotiations, and the Ardern government's policy now echoes that of the Key government in insisting that no one owns water. The ongoing political refusal to address this issue is the main obstacle to addressing most of the Land and Water Forum's remaining unactioned recommendations, 
especially those on allocation, where the forum consensus was for the trading and pricing of defined water use rights to play a key role.

Some progress has been made on iwi interests at the level of governance, especially through the creation in 2010 of the Waikato River Authority as a cogovernance entity sitting above the Waikato Regional Council. The potential for this to happen elsewhere spurred several other regional councils to establish improved mechanisms for engaging tangata whenua in council governance and policymaking. This shift has been important as te ao Māori embodies strong distinctive values on fresh water, and tangata whenua have found it difficult to win seats on regional councils through the prevailing first-pastthe-post voting system.

The role of the Environment Court in the governance system has been controversial for two reasons. The longrunning jurisprudence of 'overall balanced judgement' which gave rise to unpredictability in court judgments, enabled fudging of stated objectives and hampered accountability in the system, was overturned by the Supreme Court in the case of Environmental Defence Society $v$ NZ King Salmon ([2014] NZSC 38) in favour of clear environmental bottom lines. A second source of controversy has been the fact that the right of de novo merits appeals to the court on regional plan proposals effectively creates two hearings in most cases, contributing to the very cumbersome nature of the planning process. A lack of agility in policymaking can be unhelpful to the environmental interest by delaying much-needed change in prevailing policies which, as described earlier, are facilitating the accretion of farmer entitlements to pollute. A possible solution could involve the independent hearings panel model used to review the Auckland Unitary Plan. This model was designed (and appointed by) central government to advance urban intensification relatively quickly and effectively after decades of political impasse (Salmon, 2015).

\section{Five barriers to implementing the polluter pays principle}

New Zealand operates a market economy and competes in a globalised environment, while the government has both economic and environmental objectives. It must therefore seek policy instruments which can decouple economic growth from environmental impacts, and, in this, the polluter pays principle will inevitably play a crucial role. The central challenge is the evident difficulty in implementing this principle within the politically powerful primary sector. In institutional terms, the main barriers may be summarised as follows:

- The accreted entitlement to farm highly erodible land has institutionalised ongoing erosion and sedimentation, except to the extent that public funding is available to pay polluters to desist.

The failure to bring fresh water into public ownership by settling iwi rights and interests, and the political doctrine that 'nobody owns water', has effectively precluded charging for its use or contamination.

- The longstanding exemption of agricultural greenhouse gases from pricing mechanisms has favoured the intensification of ruminant livestock farming over less-polluting varieties of farming and forestry.

The reliance of policymakers on grandparenting arrangements in both freshwater and climate policy, without a binding exit timetable, perpetuates the accreted entitlements of established polluters.

To the extent that polluter pays depends on timely and effective regulation, the present multi-level governance design involving central and regional government and the Environment Court, in conjunction with privatised mechanisms for farmer accountability, has proven to be too dysfunctional, cumbersome and lacking in precaution to be fit for purpose.

An integrated view needs to be taken of the primary sector's environmental externalities, bringing the three key issues of biodiversity, fresh water and climate into a common framework. Once we do that, we can see that the unaccounted environmental costs are huge, and that by largely exempting agriculture from paying for these we have been hardwiring the economy into a pollution-intensive pattern of economic development. The real challenge for the government's reforms is not so much to achieve some short-term freshwater improvements in selected catchments, as to make progress on the longer-term agenda of creating institutions of integrity and effectiveness, which are capable of decoupling economic development from ongoing environmental degradation.

\footnotetext{
1 www.horizons.govt.nz/publications-feedback/one-planreviews-changes/plan-change-2. New information about attenuation of nitrogen flows between the root zone and the rivers is cited by the council in support of its proposed changes but has yet to be tested at a hearing.

2 In the case of Waiokura Stream, the Taranaki Regional Council argues that it is too small for swimming and is not representative of other intensively farmed catchments on the Mt Taranaki ring-plain because it is not directly flushed with flows off the mountain.

3 See www.manawaturiver.co.nz.
}

\section{References}

Calow, P. (2009) Blackwell's Concise Encyclopedia of Environmental Management, John Wiley and Sons

Farmers Weekly (2018) 'Aerial attack on effluent', Farmers Weekly, 4 October

Howard-Williams C., R. Davies-Colley, K. Rutherford and R. Wilcock (2011) 'Diffuse pollution and freshwater degradation: New Zealand perspectives', in E. van Bochove, P.A. Vanrolleghem, P.A. Chambers, G. Thériault, B. Novotná and M.R. Burkart (eds), Issues and Solutions to Diffuse Pollution, selected papers from the 14th international

conference of the IWA Diffuse Pollution Specialist Group, DIPCON 2010

Interim Climate Change Committee (2019) Action on Agricultural Emissions: evidence, analysis and recommendations, Wellington: Interim Climate Change Committee

Kahnemann, D. (2011) Thinking, Fast and Slow, New York: Farrar, Strauss and Giroux

Land and Water Forum (2010) A Fresh Start for Freshwater, Wellington: Land and Water Forum 
Freshwater Decline: the need for precaution and polluter pays in agriculture

Larned, S., T. Snelder, M. Unwin and G. McBride (2016) 'Water quality in New Zealand rivers: current state and trends', New Zealand Journal of Marine and Freshwater Research, 50 (3), pp.1-29

Lubell, M., A. Vedlitz, S. Zahran and L. Alston (2006) 'Collective action, environmental activism and air quality policy', Political Research Quarterly, 59 (1), pp.149-60

McNeill, J. (2008) 'The public value of regional government: how New Zealand's regional councils manage the environment', PhD dissertation, Massey University

Minister for the Environment's Technical Advisory Group (2009) Report of the Minister for the Environment's Technical Advisory Group

Ministry for the Environment and Ministry for Primary Industries (2018) Essential Freshwater: healthy water, fairly allocated, Wellington: New Zealand Government

New Zealand Business Council for Sustainable Development (2008) A Best Use Solution for New Zealand's Water Problems, Wellington: New Zealand Business Council for Sustainable Development

Olson, M. (1971) The Logic of Collective Action: public goods and the theory of groups, 2nd edn, Cambridge, Mass: Harvard University Press

Parminter, T., S. Ridsdale and S. Bryant (2018) 'The possible impact of having regional nitrogen caps on the milk production and financial viability of dairy farms in the upper Manawatu river catchment of the Tararua district', report to Horizons Regional Council

Parliamentary Commissioner for the Environment (2018) Overseer and Regulatory Oversight: Models, uncertainty and cleaning up our waterways, Wellington: Parliamentary Commissioner for the Environment

Salmon, G. (2015) 'Auckland', in L. Early, P. Howden-Chapman and M. Russell (eds), Drivers of Urban Change, Wellington: Steele Roberts Tax Working Group (2019) The Future of Tax, final report, volume 1, Wellington: New Zealand Government

Waikato Regional Council (2017) Waikato Freshwater Strategy, Hamilton: Waikato Regional Council

Wilcock, R., R. Monaghan, R. McDowell, P. Verburg, J. Horrox, C. Chague-Goff, M. Duncan, A. Rutherford, G. Zemansky, M. Scarsbrook, A. Wright-Stow, C. Howard-Williams and S. Cotton (2013a) 'Managing pollutant inputs from pastoral dairy farming to maintain water quality of a lake in a high-rainfall catchment', Marine and Freshwater Research, 64, pp.447-59

Wilcock, R., R. Monaghan, J. Quinn, M. Srinivasan, D. Houlbrooke, M. Duncan, A. Wright-Stow and M. Scarsbrook (2013b) 'Trends in water quality of five dairy farming streams in response to adoption of best practice and benefits of long-term monitoring at the catchment scale', Marine and Freshwater Research, 64, pp.401-12

Wright-Stow, A. and R. Wilcock (2017) 'Responses of stream macroinvertebrate communities and water quality of five dairy farming streams following adoption of mitigation practices', New Zealand Journal of Marine and Freshwater Research, 51 (1), pp.127-45 